\title{
Em um dia qualquer: violência, simpatia e carisma pelas tramas das audiências de custódia em Cuiabá
}

Clark Mangabeira*

\begin{abstract}
Resumo
0 presente trabalho objetiva apresentar uma visão etnográfica dos bastidores das audiências de custódia e da carceragem onde os flagranteados são acomodados, a partir da visão dos profissionais sobre os acusados, e de uma audiência tomada como metonímia das demais, a partir das categorias de violência, carisma e simpatia. 0 fio condutor são as imagens construídas dos flagranteados nas trajetórias de idas e vindas no âmbito das relações que estabelecem. 0 foco são os dizeres, minúcias e idiossincrasias que compõem a realidade social e emotiva da carceragem e de uma audiência de custódia do fórum de Cuiabá.
\end{abstract}

\section{Palavras-chave}

Violência. Carisma. Simpatia. Sistema penitenciário.

\begin{abstract}
This work aims to present an ethnographic view of the backstage of custody hearings and of the incarceration where those caught in the act are accommodated, based on the professionals' view of the defendants, and of a hearing used as a metonymy of the others, based on the categories of violence, charisma and congeniality. The guiding thread is the images constructed of those caught in the act in the trajectories of comings and goings within the scope of the relationships they establish. The focus are the words, minutiae and idiosyncrasies that make up the social and emotional reality of incarceration and of a custody hearing in the Cuiabá forum..
\end{abstract}

\section{Keywords}

Violence. Charisma. Congeniality. Prison system.

\footnotetext{
* Clark Mangabeira é doutor em Antropologia Social pelo Museu Nacional/UFRJ, é professor adjunto do Departamento de Antropologia e do Programa de Pós-Graduação em Antropologia Social da Universidade Federal de Mato Grosso - UFMT. E-mail: clarkufmt@gmail.com; mangabeira.clark@gmail.com.
} 
- Seu nome completo, jovem?

- Primeiramente, eu queria falar um negócio pro senhor... Eu menti meu nome...

- Aí sim! Você deu um nome frio lá?

- Me perdoa...

- Se arrependeu de dar o nome falso lá?

- Arrependi.

- Esse nome Mauro Silva ${ }^{1}$ é o frio, qual é o quente?

- João Silva. Eu queria chegar na frente do senhor para poder falar.

- Colocou seu dedo na máquina, chegou ao seu nome! Você tem passagem, João? Um monte, né?

- Tenho, mas eu tava tranquilo já. Faz tempo que eu não aprontava. E nesse caminho agora, eu não aprontei. O rapaz me deu o telefone dele pra mim trocar em droga, só que eu demorei, entendeu? Eu demorei. Aí ele chamou a polícia para mim. Aí quando eu voltei, a polícia estava esperando eu já. Eu não roubei, eu tinha parado de roubar...

- Quanto anos mais ou menos de condenação você tem?

- Tá tudo pago, dezessete, mas tá tudo pago. Graças a Deus. Dessa condenação minha de dezessete, eu tirei oito anos já. Tá tudo pago.

- É, mas parece que já tem um decreto de prisão preventiva seu pra sair, com decisão do juiz, lá do executivo de pena...

- Mas o que é que eu tenho que fazer? Se eu ir lá, que que eu tenho que fazer?

- Ser preso. Pra ver depois, a Defensoria vai discutir o que vai haver lá, porque você está sendo preso, por que eu não sei, pode estar descumprindo as medidas, tem que ver o porquê...

- Não tô não! Tô indo certinho!

- Você usa droga também? Pasta base?

- Sim.

$* * *$

Desde 24 de julho de 2015, quando foi promulgada a resolução 9/2015 do Tribunal de Justiça do Estado de Mato Grosso (Resolução n. 9/2015/ TP do Egrégio Tribunal de Justiça do Estado de Mato Grosso e Resolução 213 do CNJ, com fundamento no artigo $5^{\circ}$, inciso XXXV da Constituição Federal - Princípio da Inafastabilidade da Jurisdição - e Art. $7^{\circ}$, item 5, da Convenção Americana de Direitos Humanos - Pacto de San José da

\footnotetext{
${ }^{1}$ Todos os nomes foram alterados a fim de garantir o anonimato dos envolvidos.
} 
Costa Rica -, promulgada por meio do Decreto Presidencial n. 678, de 06 de novembro de 1992), a princípio (visto que, atualmente, outras varas também começaram a realizar audiências de custódia), a $11^{\circ}$ Vara Criminal do Tribunal de Justiça do Estado de Mato Grosso em Cuiabá, tem atuado na realização de audiências de custódia com os flagranteados: indivíduos que cometem delitos são transladados das delegacias de polícia para o fórum e submetidos a uma audiência de custódia no prazo máximo de vinte e quatro horas contadas a partir da prisão em flagrante. Na audiência, o juiz decide acerca da manutenção ou não do cerceamento da liberdade do acusado, bem como averigua a integridade física e mental do mesmo.

O objetivo da audiência de custódia passou a ser, na prática, consequentemente, decidir sobre a legitimidade e a necessidade da prisão, otimizando-se o serviço do Poder Judiciário, pois flagranteados que, antes da implementação das audiências de custódia, ficavam inseridos na malha burocrática do Estado por meses à espera das audiências introdutórias dos processos, atualmente, no prazo legal de vinte e quatro horas, em Cuiabá, tem seus casos analisados por um Juiz de Direito no tocante à restrição da liberdade, garantindo-se ao acusado direitos humanos básicos, tal qual preconizado na Constituição de 1988 e no Pacto de São José da Costa Rica, de 1969.

Nesse sentido, meramente legal, burocrático e objetivo, a seara da audiência de custódia, no plano do Direito, esgota-se imediatamente como um instituto garantidor dos direitos humanos dos flagranteados, bem como se trata, política e mediatamente, de um instrumento de esvaziamento dos presídios, visto que é preconizada a aplicação de medidas alternativas ao cárcere, a fim de se combater a superlotação das cadeias. Em tese, a averiguação casuística da necessidade da prisão traduz-se em uma ponderação individual sobre a trajetória do flagranteado e sobre a "real" periculosidade do indivíduo e a gravidade do seu ato, tensionando-se a decisão do juiz, a partir do contexto global do sujeito, na direção de uma possibilidade mais conveniente que não a cadeia.

Paralelamente, para além dos meandros jurídicos da audiência em si, a malha estatal destinada à custódia, em Cuiabá, introduziu o "Projeto Renascer", fruto de parceria entre a $11^{\circ}$ Vara Criminal e a Secretaria de Estado de Justiça e Direitos Humanos de Mato Grosso, a partir do qual o flagranteado, antes da audiência, é submetido a atendimento médico e psicológico, exame de corpo de delito, identificação civil e à assistência social. O objetivo é fornecer ao juiz competente, através de um documento 
preenchido antes das audiências, uma "visão global do acusado" a fim de que, por exemplo, no caso de alvará de soltura com medidas cautelares, o acusado tenha encaminhamentos determinados pelo juízo no sentido de qualificação profissional e educacional, assistência social (albergues e inclusão em programas assistenciais), medidas de saúde e acompanhamento dos casos de vício em drogas e/ou álcool etc.; ou, no caso de reclusão em presídio, o flagranteado seja encaminhado à equipe técnica de saúde e aos agentes ressocializadores com seus dados integrais, de modo a facilitar o trabalho da instituição de ressocialização. O intuito do "Projeto Renascer" é promover a inclusão do flagranteado nas redes municipal e estadual de saúde, trabalho e educação como tentativa de prevenir e combater a reincidência, em especial no caso dos réus primários com alvará de soltura.

Antes da audiência, a dinâmica do Projeto Renascer opera na tentativa de, primeiro, qualificar a situação do flagranteado de maneira a auxiliar o juiz na sua decisão, e, segundo, como "meio de passagem" entre a carceragem do fórum e a audiência, um local de apaziguamento do flagranteado conforme delineado na voz de um dos psicólogos atendentes: "aqui, o custodiado pode chorar, colocar pra fora o que está sentindo, e resumir a sua situação". O ponto nevrálgico dos atendimentos é a deteç̧ão de doenças infectocontagiosas, das situações de risco em que os flagranteados se encontram (se usuários de drogas, se possuem documentação civil etc.), o primeiro atendimento psicológico para análise do histórico do sujeito, a fim de servir de base para decisões mais apuradas do juiz, e o exame de corpo de delito, para constatar ou não qualquer violência que o custodiado tenha sofrido. Posteriormente, o flagranteado encontra-se com a defensoria pública ou advogado de defesa, a fim de preparar-se para a audiência.

Como momentos demarcados da trajetória do sujeito na malha judiciária e jurídica, os trâmites do Projeto Renascer e da audiência de custódia aparecem como dois átimos cruciais do processo do flagranteado até a sentença final condenatória ou absolutória. São momentos de demarcação de qualidades do custodiado, de primeira definição das suas idiossincrasias como indivíduos/delinquentes/cidadãos, seja na direção de continuação do processo penal, com o flagranteado preso ou não, seja na de terminar o escrutínio penal, nos casos em que houver quaisquer erros que envolvam a situação delinquente, com o consequente relaxamento da prisão em flagrante.

Anteriores à acusação formal, ao oferecimento da denúncia, consideramse bastidores do Judiciário o trâmite até a audiência de custódia e esta 
incluída, na medida em que exercem sua força agenciadora sobre o ato delinquente, sobre sua qualidade de gerador de prisão e sobre a trajetória pregressa do flagranteado, definindo-se o microuniverso da efetivação ou não da prisão preventiva ou de outras medidas cautelares. Enquanto bastidores, as realidades e "teias de significados" (GEERTZ, 1978, p. 15) que engendram a audiência de custódia e as ações do Projeto Renascer possuem uma eficácia elementar sobre - e apenas sobre - a prisão em flagrante, definindo-se, assim, primeiro, um continuum específico, com começo, meio e fim, esgotando-se sua realidade no momento da decisão do juiz sobre a privação de liberdade; e, segundo, uma resolução de um conflito prévio ao mérito da futura ação penal, a ser iniciada com o oferecimento da denúncia: a validade ou não da prisão em flagrante. Consequentemente, nesses bastidores, as dinâmicas dos envolvidos evidenciam possibilidades semânticas de percepção dos sentidos dos direitos e da criminalidade a partir de uma configuração específica, definida entre a chegada do autuado ao fórum, vindo da delegacia como preso em flagrante, e o resultado da audiência.

Nesse sentido, objetiva-se apresentar uma noção etnográfica de tais bastidores do Judiciário a partir da visão dos profissionais sobre os acusados, culminando no estudo de caso de uma audiência de custódia, cujas minúcias, falas, silêncios, emoções e ações compõem o clímax do trabalho do Projeto Renascer, àquela anterior. $\mathrm{O}$ fio condutor são os discursos e as imagens construídas dos flagranteados nas idas e vindas no âmbito do Renascer, com finalização na audiência de custódia de João Silva, dada como metonímia do coletivo de audiências.

A cena anterior de abertura é o diálogo inicial, gravado pelo próprio Poder Judiciário e disponibilizado para pesquisa, entre o flagranteado João Silva e o juiz que presidiu a audiência de custódia. Silva apresentou-se usando uma máscara médica, cirúrgica, devido à suspeita de tuberculose, percebida em atendimento feito anteriormente, na seara do Projeto Renascer.

Tendo sido recolhido pela polícia, Silva foi encaminhado ao fórum de Cuiabá às 8 horas da manhã do dia da sua audiência. Ao chegar, foi revistado pelo agente penitenciário responsável e acomodado em uma das celas nas quais ficam os flagranteados à espera das audiências de custódia, que começam por volta das 14 horas.

Por volta das 10 horas, Silva foi encaminhado às salas do Projeto Renascer. Fez exame de corpo de delito, identificação civil (quando foi 
descoberto seu verdadeiro nome) e foi atendido por enfermeiras, momento no qual foi detectada a suspeita de tuberculose e lhe dada a máscara médica. Em seguida, apresentou-se para o atendimento diante do assistente social e da psicóloga relatando o ocorrido, como se sentia e um breve retrospecto do seu passado. Fruto desse relato, foi transcrito um documento - o Plano Individualizado de Atendimento (PIA) - que passou a integrar o conjunto levado ao juiz, juntamente com o Auto de Prisão em Flagrante e a Certidão de Antecedentes Criminais.

Nesse trâmite, algemado, Silva foi levado de sala em sala sob o olhar atento dos agentes penitenciários, visto que a logística do atendimento do Renascer é da responsabilidade da Secretaria de Justiça e Direitos Humanos. O protocolo de segurança para quem está nas dependências da carceragem inclui aprendizagem sobre, por exemplo, "manter-se com as costas na parede" enquanto há trânsito dos custodiados, a fim de evitar ser surpreendido pela ação de algum custodiado. Em geral, ao meio-dia, todos os custodiados recebem alimentação e, então, aguardam o começo das audiências.

Segundo a fala dos agentes penitenciários, há três momentos bem demarcados de sociabilidade e comportamento nesse período na carceragem e no Renascer: primeiro, ao chegar e ao serem acomodados, após a revista, nas celas, os agentes indicam que "eles se acham! Ficam olhando com cara de mau, com raiva, tentando nos intimidar". Posteriormente, quando há o atendimento no Renascer, "aí eles viram santinhos...choram e se desesperam na frente do psicólogo e do assistente (social) e sabem que fizeram a coisa errada", retornando ao primeiro comportamento tão logo voltam à cela. Já na audiência, "são os coitados! Os inocentes! E dizem isso para o juiz! Não fizeram nada de errado".

Nessa dinâmica interacional com os agentes penitenciários e com a equipe do Renascer, a percepção destes acerca dos autuados aponta na direção de que os flagranteados surgem como "manipuladores" da própria imagem, alternando performances, inclusive emotivas, em momentos variados. A cada "momento performático", a violência efetivamente praticada aparece menos como fruto dos atos, já que, muitas vezes, tanto a equipe do Renascer quanto os agentes penitenciários ignoram as minúcias do crime supostamente cometido enquanto lidam com os flagranteados nos protocolos de atendimento imediato, e mais como um contexto comum de comunicação, substantivada na vida dos flagranteados e precipitada na interação com a equipe técnica, que pretende combatê-la e controlá-la. 
A violência é contextual, pois o dito e o sabido são que todos que por ali passam são violentos, independentemente do caso em si. Nas dinâmicas da carceragem, os ditos dizem menos sobre os fatos e mais sobre as vidas possíveis e vividas.

Enquanto contexto, o plano de fundo da violência, que perpassa a prática do Renascer e o lócus da carceragem, alcançando a audiência de custódia, é uma lógica comunicativa na medida em que estabelece uma classificação a priori sobre quem está ali, definindo-o como "violento" e impregnando-o de uma identidade estabelecida nos limites da carceragem e do fórum, advinda desde sua prisão em flagrante pela autoridade policial. Ademais, trata-se de uma identidade reificada por uma prática/ato criminosa latente, vívida, visto que são presos em flagrante. Sob essa classificação, as ações e interações estabelecem-se, do lado dos agentes penitenciários e da equipe do Renascer, como uma atitude acusatória por excelência, a partir da qual emergem os "bandidos".

Segundo Howard S. Becker (2008), em seus estudos sobre comportamentos desviantes, a categoria desvio surge não como qualidades de um ato/sujeito, mas como produto de um processo relacional que envolve interações específicas e processos de acusação. Para além de uma rotulação, o desvio traduz-se a partir de uma reação das pessoas a comportamentos particulares, em uma lógica bidimensional pendular entre aqueles que criam e impõem as regras e aqueles que as infringem, surgindo o desviante como elemento já previsto nas próprias normas.

No microcosmos da carceragemenas interações do Renascer, as categorias bandido ou violento, impostas de antemão, apresentam-se já definidas na interação concreta a partir de uma interação abstrata com os criminosos que virtualmente ocuparão os bancos da carceragem. Independentemente do resultado da audiência, mesmo que venha a ser solto, o sujeito que anteriormente passou pela carceragem foi tratado concretamente como criminoso, bandido, violento, definido na interação concreta com a equipe técnica e agentes a partir da virtualização interacional abstrata que designa que, ao estar ali, preso em flagrante, a violência é o plano contextual de existência daquela trajetória.

Nas teias de relações dos bastidores do Judiciário, portanto, aparece a categoria que Michel Misse (2010) chama de sujeição criminal. O rótulo de "bandido" é produzido pelo contato com a polícia e com as leis penais, aparecendo inclusive a moralidade pública como um contexto em contradição ao qual o bandido se forma (MISSE, 2010, p. 17). Ele se torna 
um agente (i)moral, ao qual são atribuídas práticas negativas e socialmente desaprováveis, e que ensejam uma reação moral proporcionalmente incisiva em relação ao ato praticado àquele sujeito que o praticou: a readequação à moral e à sociedade que o acusa e, no extremo, a eliminação física do mesmo.

Paralelamente, o sujeito sujeitado criminalmente surge com uma "subjetividade essencialmente criminosa" (MISSE, 2010, p. 19), potencialmente irrecuperável. São sujeitos que são criminalizados e não os cursos de suas ações:

Trata-se de um sujeito que "carrega" o crime em sua própria alma; não é alguém que comete crimes, mas que sempre cometerá crimes, um bandido, um sujeito perigoso, um sujeito irrecuperável, alguém que se pode desejar naturalmente que morra, que pode ser morto, que seja matável. No limite da sujeição criminal, o sujeito criminoso é aquele que pode ser morto. (MISSE, 2010, p. 21).

Surge, portanto, na perspectiva dos agentes da lei e, principalmente, dos agentes penitenciários, primeiro, a violência como contexto comunicativo e classificatório, e, segundo, a categoria violento/criminoso/bandido como definição acusatória de sujeição criminal - política, emocional e estética na interação concreta com o "desviante" em questão, montado nas rotinas, protocolos e interações - virtuais e concretas - com o flagranteado, dado como provavelmente violento, e visto que a sujeição criminal começa no plano da interação social contextual (MISSE, 2010). Nesse sentido, os momentos performáticos registrados pelos agentes penitenciários fazem sentido dentro da lógica classificatória dada previamente, sendo, portanto, dramas interacionais para, em um primeiro momento, atestar uma periculosidade praticamente irrecuperável performática diante dos demais custodiados e da equipe (quando os autuados agem com "cara de mau"), e, em um segundo momento, escamotear a pretensa realidade delitiva que os levaram até ali (quando afirmam inocência), tudo dentro da lógica comunicativa de violência dada pelo contexto da prisão em flagrante.

Por outro lado, a lógica classificatória e comunicativa que a violência imprime, de antemão, pela ocupação do espaço e da temporalidade da carceragem, aos custodiados, parece fazer desvelar, nestes, uma ação específica com fins à liberdade ante a ameaça da prisão preventiva. Aquelas diversas performances, por um lado, visam a atender e confirmar a identidadejá dada - violentos/marginais - pela localização na malhajurídica 
e enquanto uma categorização política dada em um contexto de interação entre acusados e acusadores (BECKER, 2008); e, de outro, o estabelecimento de uma forma de sociabilidade, para os custodiados, que encarna a (re) definição daquela identidade dada de antemão. Nessas malhas de tramas, os "bandidos" aparecem como sujeitos essencialmente maus, moralmente condenáveis pelo pessoal da carceragem e potencialmente configuráveis em bandidos que não só podem, como devem ser presos. Há uma preparação para o palco moral do julgamento, visto que "o crime é definido primeiramente no plano das moralidades que se tornaram hegemônicas e cuja vitória será inscrita posteriormente nos códigos jurídicos" (MISSE, 2010, p. 22).

Para Gilberto Velho (2008), a violência é parte das relações sociais "e é parte constituinte da própria natureza desta sociedade cujo universo de representações não só expressa como produz a desigualdade e a diferença" (VELHO, 2008, p. 147). As ações dos custodiados dentro do sistema do Renascer e da carceragem, portanto, envolvem a dinamização da lógica da violência na sua qualidade comunicativa, ainda que seja uma violência abstratamente considerada pela simples presença do sujeito na carceragem, uma violência que se atualiza com a entrada do custodiado no sistema via prisão em flagrante.

Por violência, entende-se a dimensão relacional que deriva da categoria desvio, ou seja, o descumprimento de regras estabelecidas para proteção da ordem pública e individual, socialmente montadas e moralmente moldadas, a partir do qual o sujeito adentra na malha jurídica. Assim, continuar, a partir do possível delito que levou ao flagrante, o contato violento dentro da carceragem com os agentes penitenciários é agenciar, minimamente, a categorização por estes imposta aqueles, confirmando-se a expectativa de plausibilidade de violência que ensejou o trajeto para a audiência de custódia. Se, desde o flagrante, impõe-se a identidade de bandido (ou qualquer sinônimo desta), o primeiro momento de enfrentamento e demarcação desse status dá-se perante os agentes penitenciários, com a consequente confirmação, para si, daquela identidade impositiva e imposta. Em outras palavras,

Impor a uma pessoa um único destino e uma identidade (uma patologia; uma classificação; um atributo essencial distintivo) fabricada com preconceitos corresponde a destruir sua liberdade, e aprisioná-la em uma única e invariável possibilidade de ser. A pessoa passa a ser prisioneira de uma imagem, uma identidade, 
uma palavra: "o problemático", "o louco", "o drogado", "o bipolar", "o agressivo", "o criminoso", "o traficante”, “o ladrão”, "a vadia", "a maluca", "a desajustada", aquela que "é assim mesmo" e "sempre foi assim" etc. As palavras variam, mas o artigo - "o" ou "a" - permanece atestando o caráter imutável da classificação (SOARES, 2011, p. 47).

$\mathrm{Na}$ imposição dessa identidade criminosa, não se diferenciando os agentes dos atos delituosos e os erroneamente encarcerados, os delitos mais e menos graves, dentro do sistema do Renascer e da carceragem, a manutenção daquela parece tornar-se uma condição sine qua non da sociabilidade na relação com os agentes penitenciários, metonimicamente considerados como a encarnação das regras cuja infringência definiu a identidade criminosa dos custodiados. A "cara de mau", a atitude agressiva, os possíveis xingamentos e os demais comportamentos são menos efetivações para si, e sim construções para outrem, dentro de um limite de expectativa razoavelmente imposto desde a apreensão do sujeito, e que este próprio pode assumir publicamente ao tornar-se indiferente ao status negativo a ele associado: "impor-se pelo medo é uma das formais mais elementares e universais de operar o poder em condições de desconfiança recíproca" (MISSE, 2010, p 26).

Na condição desse status negativo, o flagranteado representa um perigo aos outros, perigo este associado a uma subjetividade própria derivada de um "carisma de valor negativo" (MISSE, 2010, p. 27), intrínseco a sua realidade de sujeito. Consequentemente, esse carisma negativo impulsiona os sujeitos criminais na direção de maior aceitabilidade e performance de si como "bandido" diante dos outros e para outros, e pelos outros os construindo assim. O carisma negativo revela-se como um valor de diferenciação entre aqueles que são sujeitados criminalmente e aqueles que não o são, cidadãos com identidade social, em tese, distante das margens da violência, entre acusados e acusadores no contexto de moralidades aceitas socialmente.

Paralelamente, longe dos agentes penitenciários, com a assistência social e psicológica da equipe do Renascer, o choro, a lamúria, o nervosismo, as explicações e os demais comportamentos mais passivos aparecem como signos não apenas de uma performance no sentido de construção da inocência diante da rede estatal, mas também, e principalmente, como a segunda via da relação de violência de imposição daquela identidade criminosa. Tal comportamento parece não ser a negação da identidade criminosa, 
nem o oposto das atitudes de dentro da carceragem, mas outro momento do continuum identitário imposto desde o flagrante, no qual, inclusive, há possibilidades de tentativas de transmutação do carisma de caráter negativo em positivo (MISSE, 2010, p. 30), manuseando-se a interação no sentido de readequá-la minimamente à ordem legítima, a fim de se tentar reduzir a expectativa negativa já amplamente disseminada sobre o sujeito criminalizado.

De acordo com Velho (2003), a ideia de negociação de realidade leva em consideração a relação com o(s) outro(s) especificamente delineada, a partir da qual o repertório - no caso, identitário - ao alcance do sujeito é passível de manipulação. A percepção de que o outro pode entendê-los, compreendê-los, parece deslocar a atribuição identitária criminosa para uma seara não mais de primeiro plano, na qual era necessária sua confirmação para outrem, mas para um segundo plano, a partir do qual novas relações acontecem; um segundo plano construído por sobre a violência enquanto contexto definidor e interativo prioritário, em que a atuação performática da inocência ou da tristeza florescem, independentemente da veracidade delas ou não.

Enquanto um processo complexo, conflituoso e multifacetado, a negociação da realidade, na perspectiva dos custodiados em contato com a equipe do Renascer e mesmo diante do juiz na audiência que julgará a possibilidade de liberdade, precipita novamente a violência estabelecida desde a prisão em flagrante: não é (somente) porque querem demonstrar que são inocentes - embora, às vezes o sejam - que os custodiados agem emotivamente e passivamente, a fim de atestar aquela inocência, diante de psicólogos, assistentes sociais e juízes; é porque são reconhecidos e passaram a se autoidentificar como violentos, não mais tendo que confirmar externamente a identidade violenta lhes imposta pelos agentes representantes da força na/da lei na carceragem e na delegacia, que o comportamento do choro ou do nervosismo acontece, sendo passível de experimentação; exatamente na medida em que a violência lhes imprimiu a identidade, o nervosismo, mesmo mínimo, nessas novas interações com novos interlocutores mais afastados do poder de polícia (assistência social, enfermeiras, psicólogos etc.), é plausível de ocorrência. Em outras palavras, é porque, agora, percebem que todos creem na violência identitária dos sujeitos acusados, que a possibilidade de inocência pode aparecer; é devido ao fato de que agora entendem que os consideram violentos - afinal, estão na carceragem presos em flagrante - que, diante dos psicólogos, uma 
catarse emotiva efetiva-se, sedimentando a identidade criminosa imposta para os próprios acusados, independentemente da violência ou não de fato praticada.

Trata-se de um segundo nível de violência - para além da do fato que levou o custodiado à carceragem e da caracterização violenta dada por terceiros. Uma metaviolência, fruto da identidade imposta, e, pela catarse, normalmente verificada nas conversas, absorvida pelo autuado, encarnada enquanto um bandido, seja ele de fato um ou não:

Várias possibilidades são vetadas a essa pessoa de cuja identidade,
em alguma medida, nós - escola, família, condomínio, médicos,
comunidade - tomamos posse, de antemão e independentemente
do que ela mesma queira. Esse é o ponto de impacto de ações
externas que reduzem a liberdade do ser. Aí incide uma força
poderosa e castradora: eis a violência operando, fazendo seu
trabalho sujo, talvez imperceptível para quem observa de fora,
mas profundamente doloroso e marcante para quem o sofre
(SOARES, 2011, p. 47).

Assim, se a possibilidade da percepção da inocência já aparece abstratamente vetada para o custodiado, a entrega ao desespero é, ato contínuo violento, uma reafirmação da identidade violenta a ele dada, e mantida anteriormente, por ele, para outrem. No caso em tela, por exemplo, Silva, diante do juiz, reforça que "estava tranquilo", que fazia tempo "que eu não aprontava. E nesse caminho agora, eu não aprontei". Ora, para além do fato de que Silva sabe que o juiz possui seus antecedentes criminais, usar essa informação diante do mesmo parece ser fruto do entendimento de si e para si de que, naquele contexto interativo, ser violento lhe é uma identidade imposta estabelecida. Daí, para além de tentar demonstrar ao juiz sua trajetória mais "tranquila" e tentar, assim, a liberdade, reafirmando que já cumprira suas penas, a metaviolência aparece na própria introspecção de que não os atos, o em julgamento e os anteriores, são/foram criminosos, mas que sua trajetória resplandece delinquente. Atos e fatos perdem espaço para o criminoso presencialmente atestando-se criminoso pela sua identidade construída, principalmente, pelos outros. Consequentemente, as reações emotivas surgem como nível da percepção de si fruto daquela identidade imposta, e não apenas como mera performance tendente à definição de inocência.

Por fim, a violência, enquanto marca identitária fruto de interações na seara jurídica, é tão afirmativa que o resultado do atendimento no Renascer, 
os múltiplos planos de identificação e documentação culminam no Plano Individualizado de Atendimento, que seguirá para o juiz para municiá-lo na decisão pela liberdade ou prisão preventiva. Consolida-se o resultado das diversas interações em um documento, um ato classificatório da pessoa (e não do fato praticado), em tese fundamental para a decisão magistrada, mas que parece ser outra marca, agora concreta, das diversas contextualizações pela qual passou o custodiado desde a prisão.

- Da sua prisão até agora, teve alguma violação dos seus direitos?

- Não, nada.

- Com a palavra, doutora promotora...

- Nenhum questionamento, obrigada.

- Doutora defensora...

- O João está sendo acusado de roubo de celular. O senhor pode dizer o que aconteceu? Foi encontrado algum celular com você?

- Não! Não acharam nada comigo! O rapaz que está acusando eu chamou eu para pegar uma droga para ele. Aí, me deu dez reais. Eu fui e peguei a droga. Aí, nós fumamos, o dinheiro dele acabou e ele disse "você pode vender meu celular lá? Vende lá o celular pra nós fumar". Aí nessa eu peguei o celular dele e fui lá vender, entendeu? Aí demorei muito, porque ninguém estava querendo comprar. Aí nisso ele chamou a polícia. Aí quando eu voltei, a polícia já estava esperando eu já. Só que aí eu devolvi o celular dele, devolvi tudo. Só que mesmo assim, me indiciaram. Não teve roubo. Não teve nada.

- Você acredita que ele disse que foi roubado por você por quê?

- Porque ele ficou com medo de perder o telefone... e não usar a droga.

- Tá certo. Sem mais perguntas.

$[\ldots]$

- Promotora, com a palavra.

- Meritíssimo juiz, o flagrante encontra-se em ordem também em relação a esse autuado, razão pela qual o Ministério Público pugna pela sua homologação. O Parquet entende ainda que é o caso de conversão da prisão em flagrante em preventiva em razão do seguinte: trata-se de roubo majorado pelo concurso de agentes. São duas vítimas, a ordem pública se faz necessária de ser mantida nos termos do artigo 312 do Código de Processo Penal. A vida pregressa do autuado lhe é deveras desfavorável, tendo ele ainda condenação anterior por crime transitado em julgado, de modo que se atende ao artigo 313, inciso II, do mesmo estatuto. A pena cominada ao 
ilícito também autoriza a segregação, atendendo ao artigo 313, inciso I, do Código de Processo Penal. O autuado praticou ilícito contra a vítima Paulo e contra a vítima Gustavo, embora Paulo não o tenha reconhecido, a vítima Gustavo o reconheceu com absoluta certeza como sendo o autor do ilícito. O Ministério Público entende ainda que o fato de ele ter mentido seu nome perante a autoridade policial, embora tenho dito o nome verdadeiro agora em juízo, configura sim o ilícito de falsa identidade, de modo que também se vê ameaçada a aplicação da lei penal. Por todo exposto, o Parquet espera ver convertida a prisão flagrante em preventiva. É como manifesto.

- Defesa, com a palavra...

- Excelência, trata-se de Auto de Prisão em Flagrante contra João Silva. $\mathrm{O}$ acusado foi ouvido nesta audiência, oportunidade em que narrou os fatos de forma bastante semelhante ao que narrou na delegacia, negando ter cometido o referido assalto e relatando que a vítima o teria acusado de roubo porque teria pedido a ele para buscar droga, em troca de um celular, e quando viu este nas mãos da polícia, em tempo de tê-lo de volta e com medo de uma represália, teria dito que o referido bem teria sido roubado. É importante salientar que nenhuma arma de fogo foi encontrada com o acusado, nem tampouco a res furtiva. Resta somente a palavra da vítima. Encarcerá-lo preventivamente com base apenas em seus antecedentes é medida de injustiça. A defesa entende que não estão presentes os requisitos autorizadores da preventiva e que deve ser dada ao acusado a liberdade provisória. E em não sendo este o entendimento de Vossa Excelência, que lhe seja imposta qualquer uma das cautelares elencadas do artigo 319, como tornozeleira eletrônica ou coisa do tipo, já que o mesmo, reitero, não infringe nenhum dos requisitos ensejadores da preventiva. Encerro.

No mesmo dia da audiência de Silva, houve outras cinco. A dinâmica leva, em média, doze minutos até a decisão do magistrado. Depois do atendimento na carceragem e das dinâmicas do Renascer, e após o almoço, Silva aguardou o chamado dos agentes a fim de seguir para a antessala do Sala de Audiência, onde o juiz, a promotora e a defensora esperavamno. Sem algemas, apenas com a máscara cirúrgica, sentou-se e começou a sessão.

Em todo o percurso pelos bastidores, da chegada do custodiado ao fórum ao final da audiência de custódia, com o consequente encaminhamento do autuado à liberdade ou ao presídio, o tom da discussão sobre a violência em primeiro plano, do ato, e, em segundo, da própria pessoa do acusado 
- gira em torno do cotidiano dos fatos e da trajetória do sujeito, do dia a dia no qual a realidade delituosa, em tese, ocorreu. Segundo um dos juízes que atuam na custódia, "aqui é a criminalidade mais básica, do dia a dia, mais simples, e temos que conversar nesse tom".

De acordo com Veena Das (2007), a narração e a análise de eventos devem ser escrutinadas na medida em que se vinculam ao cotidiano, nas cavidades da vida ordinária, enquanto um fenômeno atrelado à singularidade das vidas a ele conectadas. Nesse sentido, Das (2007) concebe a ordinariedade da violência, na qual os atos violentos devem ser percebidos - e narrados - em uma linguagem rotineira e ordinária, intrínseca das relações. A violência praticada pelos flagranteados deve ser, portanto, percebida como uma linguagem do plano ordinário de vivência e construção de si - a partir de si e dos outros -, na qual a trajetória do acusado é avaliada e reavaliada pelo mesmo e pelos interlocutores em contextos específicos, considerandose perspectivas singulares.

Na esteira de Das (2007), a audiência de custódia é uma zona de fluxos e refluxos de narrativas e estéticas na qual o evento delitivo é narrado de diversas maneiras, revisitado na tentativa de concebê-lo sempre na sua ordinariedade, seja a pragmática, seja a jurídica, a fim de estabelecer, por fim, a possibilidade ou não da liberdade.

Nesse jogo de interações, de um lado, a relação dos agentes do Estado, em especial da defesa, com o autuado em tela, João Silva, estabelece a ordinariedade pragmática do evento, tratando-o narrativamente isolado da linha da trajetória do custodiado. Ao ser indagado, Silva conta o fato a partir da sua própria perspectiva, enquanto e apenas como um evento vivido - e, deste modo, uma violência ordinária, acontecida, isolada. $\mathrm{O}$ foco recai sobre o que aconteceu, como aconteceu, sobre o evento em si, mundanamente considerado dentro da esfera de ação pretérita. Consequentemente, Silva narra o fato destacando que "não houve roubo", mas um mal-entendido.

Por outro lado, as interações entre os agentes do Estado estabelecem uma estética narrativa que realocam o evento dentro da trajetória do custodiado, estabelecendo a violência não como uma qualidade do fato, mas como uma virtualidade do flagranteado, reforçando a identidade estabelecida na carceragem. A discussão passa a ser de uma temporalidade que se irradia, a partir do evento, para trás (há um mandado de prisão contra Silva por outros delitos) e para frente (pela ordem pública, o Ministério Público considera a prisão necessária, bem como uma nova acusação por falsa identidade). O evento delitivo, encarado, na perspectiva dos agentes da lei, como algo 
rotineiro devido à trajetória do acusado, estabelece a discussão da violência sob o condão da ordinariedade jurídica da pessoa, de maneira que é a qualidade de Silva, suas idiossincrasias, que determinam a potencialidade delitiva e a periculosidade, independentemente do fato em análise (ponto, inclusive, destacado pela defesa na tentativa de convencer pela liberdade).

Da interação entre juiz, Ministério Público e defesa, Silva torna-se espectador, pois já participara no que lhe era devido, primeiro, com suas "qualidades" de potencial criminoso tendo sido registradas por terceiros nos documentos que o acompanharam - PIA, auto de prisão em flagrante, ficha criminal etc. -, elementos que compõem o ato classificatório da pessoa; segundo, narrando o evento nas fendas da sua ordinariedade, visto que o sujeito aparece como o limite de experimentação do mundo (DAS, 2007), de modo que o assalto é perspectivamente analisado por Silva.

Já juiz, Ministério Público e defesa, entre si, interagem de forma diversa, a partir do jargão jurídico, definindo o futuro de Silva. Enquanto na relação com o autuado, o fato é verificado como um evento pessoal (BARTH, 2000, p. 131), a partir da perspectiva sincrônica de narrativa e memória; na relação entre os agentes estatais, consideram-se a trajetória do autuado e a potencialidade diacrônica de uma carreira criminal, sendo esta a esfera relevante para a concessão ou não da liberdade. Entre ambas as versões, surge Silva, identificado de antemão como violento/criminoso/bandido, cuja prisão ou liberdade depende não apenas do acontecido, mas das identidades, narrativas, influências e virtualidades que pairam sobre ele dentro do processo nesses bastidores do Judiciário.

Nesse contexto, surge a simpatia como uma categoria micropolítica emotiva de construção de relações que pode ajudar na compreensão das interações que se estabelecem entre os membros do Judiciário e o acusado. Candace Clark (1997) designa a simpatia como uma das "colas" da sociedade, através da qual uma pessoa se conecta com outra. Caso não haja simpatia por outrem, não se estabelece nenhuma relação. Ademais, a simpatia pode, ao mesmo tempo, estabelecer diferenças hierárquicas entre quem "oferece simpatia" e quem "recebe a simpatia", entre simpatizantes e simpatizados, através das quais o simpatizado reage a uma possível atitude emocional do simpatizante, sabendo exatamente como, quando e onde pedir simpatia como parte de uma economia socioemocional específica, e sabendo que está hierarquicamente inferior ao simpatizante devido ao contexto de necessitar de simpatia. De forma direta, consequentemente, Clark (1997) entende simpatia como uma forma de interação social e um 
antídoto para a tristeza da vida, um "ingrediente de apego" (CLARK, 1997, p. 11) das relações sociais enquanto parte do código moral das mesmas, uma "emoção social" que conecta atores sociais (CLARK, 1997, p. 31).

No caso de Silva, enquanto simpatizado em atividade, o choro e as tentativas de buscar, diante do juiz, o relaxamento da prisão parecem se enquadrar exatamente no papel ativo de quem está hierarquicamente subordinado ao contexto, ao papel de quem depende de simpatia para se ver livre da situação problemática. A narrativa do evento por Silva, com detalhes e emocionalmente construída desde a revelação da mentira sobre o nome, tentando fazer-se como um sujeito não criminoso, pretende despertar a simpatia necessária entre dois sujeitos em hierarquias distintas para eles se conectarem em prol da liberdade de Silva. A dinâmica da relação entre defesa e juiz, que conversam com Silva, e mesmo diante do Ministério Público, que não pergunta nada sobre o evento ocorrido e apenas se manifesta juridicamente sobre o caso em si, transmuta-se na atitude de Silva de tentar despertar simpatia com sua sinceridade. Mesmo na seara mais ampla dos relatos dos agentes que demarcam as atitudes dos acusados que passam pelo Renasce e pela carceragem, estar diante do juiz como inocentes, e diante do psicólogo e do assistente social como "bonzinhos", emocionalmente abalados, faz parte do papel do simpatizado de se construir na interação com o simpatizante, a fim de tentar escapar do caráter negativo da sujeição criminal a que está enquadrado de antemão. Nesse jogo, entrando em choque o evento e a construção da pessoa, é naquelas teias de narrativas que a resolução do ato se resolve.

Enfim, portanto, em silêncio, Silva recebe a decisão, o ato resolutório do tópico, clímax de todo o bastidor, do trabalho iniciado na carceragem, passando pelo Renascer, e da própria audiência de custódia. Nesse microcosmo, o foco não é o mérito jurídico do fato, mas a efervescência identitária de Silva em sua trajetória de vida. A prisão ou a liberdade operam como signos que confirmam ou redesignam a vida do sujeito, contudo sempre o classificando e configurando-o a partir do evento considerado dentro da sua ordinariedade, do cotidiano dos caminhos de Silva. Restam silêncios e futuros, possíveis e impossíveis, continuados para além do bastidor, quando a ação penal for instaurada e novos méritos, questões, performances e perspectivas forem acrescentadas na malha jurídica do caso. Até lá, é a liberdade ou a prisão o mote da classificação mais geral de vidas e fatos, resolvidas pela e na audiência de custódia. 
- Olha, primeiro, a doutora promotora solicitou, então temos que abrir um processinho contra você, porque você usou um nome falso lá na delegacia, isso é um crime previsto no artigo 307 do Código Penal. Em segundo lugar, a vítima te reconheceu no roubo. Até averiguar essa situação, você vai ter que ficar recolhido. E tem um mandado de prisão seu lá na Execução Penal, vai ter que ser averiguada essa situação também, tá?...

- Então... eu vou ficar preso então?

- Não tem como sair, tá? Pode levar ele.

\section{Referências}

BAILEY, F. G.

(1983). The Tactical Uses of Passion. An essay on power, reason and reality. Ithaca and London: Cornell University Press.

BARTH, Fredrik.

(2000). 0 guru, o iniciador e outras variações antropológicas. Rio de Janeiro: Contra Capa Livraria.

BECKER, Howard S.

(2008). Outsiders. Rio de Janeiro: Zahar.

CLARK, Candace.

(1997). Misery and company: sympathy in everyday life. Londres: The University of Chicago Press.

DAS, Veena.

(2007). Life and Words: Violence and the descent into the ordinary. Berkeley: University of California Press.

GEERTZ, Clifford.

(1978). A Interpretação das Culturas. Rio de Janeiro: Jorge Zahar Ed.

LIMA; RATTON; AZEVEDO (orgs.).

(2014). Crime, polícia e justiça no Brasil. São Paulo: Contexto.
MISSE, Michel.

(2010). Crime, sujeito e sujeição criminal: aspectos de uma contribuição analítica sobre a categoria "bandido". Lua Nova, n.79, pp.15-38.

SOARES, Luiz Eduardo.

(2011). Justiça: pensando alto sobre violência, crime e castigo. Rio de Janeiro: Nova Fronteira.

VELH0, Gilberto.

(2003). Projeto e metamorfose: antropologia das sociedades complexas. Rio de Janeiro: Jorge Zahar Ed.

VELH0, Gilberto.

(2008). Individualismo e cultura: notas para uma antropologia das sociedades complexas. Rio de Janeiro: Jorge Zahar Ed.

\section{Recebido em}

agosto de 2018

\section{Aprovado em}

fevereiro de 2019 